\title{
The Vulnerability of Imperial Language as a Transformational Tool in Postcolonial Transcultural Discourse
}

\author{
Charles Ngiewih Teke, PhD \\ Associate Professor, Senior European Union Researcher, MC - IIF \\ Department of English and American Studies, Ludwig-Maximilians University, Munich \\ teke@anglistik.uni-muenchen.de, tekengiewih@yahoo.com
}

\author{
Doi:10.5901/ajis.2013.v2n3p71
}

\begin{abstract}
This essay reassesses the complex and unending debate on the use of imperial language, particularly English, as a plausible postcolonial transformational asset. Arguing against previously held convictions that imperial language is a cultural capital and marker of dominance or the core of Western cultural representation, the contention of the paper situates imperial language as fragile, non indicative as carrier of Western epistemology and as vulnerable in the hands of the postcolonial writer who uses it to translate and ascertain his cultural identity and epistemology. Different postcolonial writing strategies include such issues as menace, sly mimicry, subversion, appropriation, abrogation and accommodation. English language in its varieties assumes a cosmopolitan character, and is used at times metonymically, that is, including writers' own language without them necessarily undoing their cultural heritage. The essay concludes that, English is a power-generating metaphor; it is mutually constitutive, engendering both the coloniser and colonised as repositories or sites of power. In this matrix, English is used in the postcolony for cultural transmission and for the alteration of colonial and imperial dominance. Postcolonial writers are not bondsmen, but committed agents in the polyvocality of cultures and other diverse discourses in postcolonial spaces and the ever changing global context.
\end{abstract}

Keywords: Vulnerability, imperial language, cultural epistemology, transcultural discourse, postcolonial transformation, subversive mimicry

\begin{abstract}
'Mes rapports avec la langue française sont des rapports de force. J'écris en français parce que c'est dans cette langue-là que le peuple dont je témoigne, a été violé, que moi-même j'ai été violé. Je me souviens de ma virginité. Et mes rapports avec la langue française sont des rapports de force majeure, oui, finalement. II faut dire s'il y a du français et de moi quelqu'un qui soit en position de force, ce n'est pas le français, c'est moi. Je n'ai jamais eu recours au français, c'est lui qui a recours à moi' Sony Labou Tansi

[My relationship with the French language is that of force] I write in French because that is the language in which the people I speak for were raped, that is the language in which I myself was raped. I remember my virginity ... One must say that if between myself and French there is anyone who is in a position of strength, it is not the French, but I. I have never had recourse to French, it is rather French that has had recourse to me. (Thomas 2002: 86)
\end{abstract}

\section{Introduction}

This excerpt explicitly represents what I would call linguistic interpolation and an overwhelmingly triumphant narcissistic attitude against narcissism itself. It shows the significant degree of interruption of the grand narrative from a linguistic dimension, the veritable triumphant liberation out of the bondage of cultural enslavement. The excerpt is not about Molière, Racine, Voltaire, Balzac, Pascal, Bovary, Baudelaire etc. whom imperial French assimilationist policies would have wanted postcolonial subjects to unconditionally engage with and internalise. The excerpt is not the glorification of imperial French linguistic and cultural tyranny. It is inscribed in a retroactive reflection of colonial and imperial experience and the author's re-orientation of language as powerful instrument of counter-discourse to imperialist and ethnocentric epistemology. It is about Africa, its experiences, its realities, its concepts, its meanings, its images, its voices, its agency, its capture and defeat of a vulnerable imperial asset, language. The French language is positioned here at a point of conquest and fragility. What, therefore, are the critical implications of Sony Labou Tansi's philosophical statement on the use of imperial language as medium of disruption and decentring, as a medium of representation and resistance in a wider range of postcolonial writing and criticism?

In what follows in this essay, the vulnerability of imperial language as a transformational tool in postcolonial 
transcultural discourse re-ignites the highly controversial and unsettling debate about the nature of postcolonial use of colonialist language as medium not only of expression but more importantly as a cultural and ideological vector. It engages in further reflection by probing into present semantic instabilities surrounding English language as native language, second language, foreign language and international language, and how writers' use of this language persists in the direction of undermining its once hegemonic power. Language, far from being a neutral communicative tool, is discursive and engages new referents in new locations. Imperialist languages such as English, French, Spanish and Portuguese carried imprints of Western epistemologies of dominance, but were paradoxically dominated within the matrix of anti-colonialist struggles which used these same languages as strategic assets in quite different communicative and discursive contexts. This linguistic susceptibility disrupts imperial language as unique cultural capital and repositions the language in a myriad of cultural, anthropological, philosophical and ideological contexts.

Bill Ashcroft has theoretically rendered Tansian thinking more visible when he conjectures that

Post-colonial writing hinges on the act of engagement which takes the dominant language and uses it to express the most deeply felt issues of post-colonial social, political and cultural experience. This form of 'imitation' becomes the key to transforming not only the imitator but the imitated. The engagement of post-colonial writing is one which had transcultural influences, that is, dialectic and circulating effects which have become a crucial feature of the world we experience today. (Ashcroft 2001: 5)

What one discerns is the susceptibility of imperial language in the possession of the postcolonial 'subject', and the clear demonstration that imperial language ceases to be a symbol of dominance over the colonised and instead serves as a weapon of attack or redress against the coloniser. Postcolonial creative writing and theoretical discourse provide ample space for such transformations and refresh the question of the use of imperial language as perpetuating Western dominance and undermining or neutralising African languages and cultures. The essay purports to ascertain the conviction that, in today's postcolonialist debates, the use of English in creative expression does not betray African cultural distinctions - English does not mean Britain, Shakespeare or Dickens, just like French does not mean France, Racine or Voltaire and Spanish does not mean Spain, Miguel de Cervantes or Luis Prieto. Rather, theses languages are nuanced into new mirrors which reflect images and meanings different from imperialist designs. Colonialism and imperialism never annihilated the vibrancy of African languages and cultures, for example. These languages flourish; Africa's cultures have not been mortgaged with recourse to imperial languages. Cosmopolitan transformations and alterations have, on the contrary, enriched the postcolony which emerges as genuine and authentic synergistic global space.

Ashcroft argues further that the "adulteration/abuse of the master language enable them [postcolonial writers] to express what cannot be adequately captured in the original language" (Ashcroft 2004:75). Postcolonial writers' strategies in this vein consist in linguistic deviations characterised by distorting standard lexicons and syntaxes, and creating new lexicons and structures to suit contextually lived experiences. Tansi was expert in this new linguistic colonialism and appropriation of the master's code and beyond. Many Anglophone African writers and thinkers have followed the path of this thinking. The English language is a strategic cultural and transcultural vector in postcolonial contexts. Writers such as Soyinka, Okigbo, Ngugi wa Thiong'o, Achebe, Armah, Asong, Kishani, Butake, Nkengasong and Alobwed'Epie have amply demonstrated this act of cultural intelligence with impacting results. Culture is not fixed, it is not static and in a consciousness of global connectivity, positive and productive transformation is inevitable. Language by extension cannot be hegemonic; it travels and changes; it is altered, domesticated and adapted in different locations and circumstances; it can be used for purposes other than what it seems to represent. Part of the survival of African cultures has been enhanced by the reconditioning of the master code. This has not deterred the development of African languages which have their own flourishing space in the continent and global cultural market.

\section{The Location of Imperial Language}

In traditionalist and romantic postcolonial criticism, imperial language has always been considered the greatest weapon of cultural dominance, assimilation and at times destruction and annihilation (Chenweizu et al., Ngugi wa Thiong'o, Tanure Ojaide, Frantz Fanon etc.). The tenability of this point in the initial time axes of the colonial and imperial enterprise is undoubted. However, with regard to contemporary transcultural awareness in which expressions such as purity, originality, authenticity and totality are outmoded, the position of the advocates of an essentialist African aesthetics and culture is not acceptable. The early Ngugi is remarkable for having radicalised his position on the polemic, dismissing English as his language of creative engagement, continuing his theoretical writings in English though, and condescending 
to translations as offering opportunities for wider dissemination of his creative work in Gikuyu or Kiswahili. Decolonising the Mind: The Politics of Language in African Literature ([1987] 1994) expresses Ngugi's thoughts about authentic and genuine African literature written in African languages, as opposed to what one might call a kind of artificial literature or Afro-European literature as Ngugi himself considered it. In Moving the Centre: The Struggle for Cultural Freedoms (1993) he uncompromisingly proposed Kiswahili as a world language, while acknowledging English, French, Spanish, etc. as languages in their own right, but not in the right to dominate over other languages and cultures (41).

Much has been written, indeed, against the cultural and linguistic totalisation of the West, curiously in the very language against which the attacks are directed. Current research trends are still alive with the issue. Frantz Fanon (1963) called for the total rejection of French cultural imperialism in French language. Chenweizu et al. (1983) decried cultural, literary and theoretical imperialism in the very language of the imperialist, English. Ngugi wa Thiong'o (1993) denounced English in English and has still been engaged with the language even if not in the sphere of creative writing. Kunene (1992) and Owomoyela (1992) argued in English that African thinking could best be described and transcribed only in African languages. Tanure $(1996,2012)$ theorises about total African aesthetics through the medium of English. It is in English that Walcott (2006) contends that mastery of the coloniser's language does not connote victory but a new form of bondage and linguistic servitude. Can exclusion and totality be acceptable lexicons of cultural identity and representation in today's transcultural and cosmopolitan transactions?

Far from being ironical or paradoxical, this language situation is an act of positive subversion, of shrewd mastery. Some of the compelling questions with which this essay wrestles are: is language the sum total of cultural identity and representation? Can a culture be defined only by its language? Are there no other authentic cultural signposts apart from language? Can the debate on language be transcended without a culture losing all the varieties of its uniqueness? Where actually is imperial language located today? Can English be excluded in postcolonial transcultural spaces? Is, for example, writing in English the equivalence of Anglo-centrism? Are all the writers listed above in essence Afro-European? Have they continued to entangle African culture or failed to move the centre because they write in English? Is Sony Labou Tansi's case above not, on the contrary, a pointer that Francophonie's fallacious assimilationist centrism can be outwitted and disrupted? Have notions of native speakers of imperial languages not been deconstructed in the postcolony?

African postcolonial studies have continued to critically evaluate the big paradox which lies in the heart of the use of the coloniser's language (Adejunmobi 1999, Asante-Darko 2000, Ambanasom 2001, Afolayan 2002, Pacheco Pinto 2010, Guthrie 2011). This essay contributes to the ongoing debate however imperceptible. "Writing back" has usually been characterised by oppositionality inscribed within the Western-styled binary dichotomies. The fight, curiously, has always been engaged in the colonialist's language. Why? New literatures in English, or better still varieties of English in different former colonialist locations, are a mark of the futility of any attempt to impose a particular brand of the coloniser's language on the colonised subject whose cultural contexts mark different linguistic routes and semantic trajectories.

Salman Rushdie's cosmopolitan view of English in Imaginary Homelands is worth examining to show how postcolonial locations can distance themselves from English from a colonial/imperial and metropolitan perspective:

\begin{abstract}
One of the changes [in the location of anglophone writers of Indian descent] has to do with attitudes towards the use of English. Many have referred to the argument about the appropriateness of this language to Indian themes. And I hope all of us share the opinion that we can't simply use the language the way the British did; that it needs remaking for our own purposes. Those of us who do use English do so in spite of our ambiguity towards it, or perhaps because of that, perhaps because we can find in that linguistic struggle a reflection of other struggles taking place in the real world, struggles between the cultures within ourselves and the influences at work upon our societies. To conquer English may be to complete the process of making ourselves free. (17)
\end{abstract}

Rushdie contends that new Englishes disrupt and dismantle metropolitan undertones, providing a linguistic continuum in which the language becomes a therapeutic act of resistance and freedom in colonised locations without erasing ambiguity towards it. One would understand, no doubt, that this ambiguity is the very anxiety of using a foreign language as referent in place of the colony's own natural linguistic code. But the nativisation of English is an act of delocalising and re-localising its imperial metropolitan character into a hybrid cosmopolitan space; it is a strategy, conscious or unconscious, of constraining and of eroding language as the soul or nucleus of a culture. English can no longer be referred to as imperial language in contemporary postcolonial articulations. As Rushdie rightly, says it has been conquered as part of the process of unyoking cultural dominance. Its use in the postcolony does not carry with it imprints of the English culture anymore. It remains an imperial language in the annals of colonialism and imperialism only in Britain, however complex its varieties in this same location appear to be. Its inscription in cosmopolitanism presupposes 
its devaluation as an essentialising metropolitan and unidirectional communicative and cultural model.

Rushdie's view echoes that of another seminal Indian writer/critic, R. K. Narayan, who has observed that

We cannot write like the English. We should not. We cannot write only as Indians. We have grown to look at the large world as a part of us. English both is and isn't 'an alien language'; it is the language of Indians' 'intellectual make-up' but not of 'their emotional make-up'. (Narayan 1988:53)

Narayan's argument once more puts the debate into a wider spectrum on postcolonial studies with regard to how English is appropriated to questions of history, politics, power, identity, and cultural and social consciousness within and without the postcolony. The term "emotional make-up" is very metaphorical and designates other Indian cultural repositories. English language's inscription in the matrix of ambiguity means its broadening in elastic spaces of diverse tropes. The excerpt explicitly signals language's inability to represent all aspects of culture, justifying the contention of this paper that language cannot be the unique nerve centre of cultural identity and representation.

In Africa, Chinua Achebe had taken a significantly firm stance on the question of the capitulation of English as a uni-discursive or monolithic imperial code. In his famous and widely quoted essay on this issue, "English and the African Writer," he is unequivocal on using English without being Anglicised:

What I do see is a new voice coming out of Africa, speaking of African experience in a world-wide language. So my answer to the question, Can an African ever learn English well enough to be able to use it effectively in creative writing? is certainly yes. If on the other hand you ask: Can he ever learn to use it like a native speaker? I should say, I hope not. It is neither necessary nor desirable for him to be able to do so. The price a world language must be prepared to pay is submission to many different kinds of use. (29)

Achebe has never felt guilty of betraying his native Ibo or Africa and his literary texts attest to the fact that he was a cultural nationalist, though not on essentialist but transcultural grounds. The vulnerability of English is registered in its inevitable submission to multiple uses. Many writers have subscribed to his thinking without mortgaging their cultural origins and affiliations.

\section{Subversive Imitation (Mimicry): Through the Looking Glass and Disruption}

With whose prism should postcolonial use of imperial language be viewed? What images does this language produce or reflect? Whose looking glass produces meaning, contextual meaning, and meaning in the metaphorical sense of beauty in the eyes of the beholder? Just how complex is linguistic mirroring amidst different locations of culture? By nature, mirrors are subversive; they invert. Can one say language is metaphorically a mirror in this perspective?

Lewis Carroll has provided a clue which can be used in attempting these unsettling questions. In the unabridged version of Through the Looking Glass, a sequel to Alice in Wonderland and certainly more than children's literature, the display of linguistic limitation and liberalism can be contextualised in this essay:

"I don't know what you mean by 'glory'," Alice said.

Humpty Dumpty smiled contemptuously. "Of course you don't - till I tell you. I meant 'there's a nice knock-down argument for you!"”

"But 'glory' doesn't mean 'a nice knock-down argument'," Alice objected.

"When I use a word," Humpty Dumpty said, in rather a scornful tone, "it means just what I choose it to mean - neither more nor less."

"The question is," said Alice, "whether you can make words mean so many different things."

"The question is," said Humpty Dumpty, "which is to be master - that's all."

Alice was too much puzzled to say anything; so after a minute Humpty Dumpty began again. "They've a temper some of them - particularly verbs: they're the proudest - adjectives you can do anything with, but not verbs -however, I can manage the whole lot of them! Impenetrability! That's what I say!"

Who is the linguistic master in this complex conversation which one can consider a metaphorical dialectic? Humpty Dumpty is the sly user of the language, as opposed to Alice's mere illusion of mastering language and her inability to shift between pluralities in semantic fields. In other words, Humpty Dumpty can be construed as the postcolonial subject/writer and master of his 'master's' language, while Alice represents the imperial code which only appears to be superior and self-sufficient. Alice's puzzle, bewilderment and anxiety should be that of the imperialist who is caught in his own web of knowledge and whose ways of knowing are seriously undermined and delimiting. Humpty Dumpty's subversion or 
inversion of language is not necessarily aimed at concealing meaning; he is rather implying that, epistemologically speaking, meaning has no centre or fixity. The use of the same word will largely depend on understanding where and the way it is intended to be used. Semantic instability does not mean semantic impossibility. It presupposes a rich continuum of multiple and plausible discourses generated from complex myriad contexts.

Ashcroft et al.'s The Empire Writes Back and Ashcroft's Post-colonial Transformation are determining texts in this debate. In the former text, two terms are given to analyse the processes through which imperial language loses its totalising essence. These are "abrogation" and "accommodation": Abrogation is a refusal of the categories of the imperial culture, its aesthetic, its illusory standard of normative or "correct" usage, and its assumption of a traditional and fixed meaning "inscribed" in the words (38). Appropriation is the process by which the language is made to "bear the burden" of one's own cultural experience ... Language is adopted as a tool and utilised to express widely differing cultural experiences (38-39). One would understand here that appropriation and adoption neutralise cultural imprints of the colonial language which becomes a valued asset in postcolonial transformations.

Revisionist attitudes in mimicry are explicit in the strategic position of not only an extended but equally new master of language. The Western reader of English, a supposed master of the language, has to be very careful in reading texts from the postcolony to uncover the layers of meanings explicitly or implicitly inscribed therein. He too needs to be colonised in the making of meaning. In fact, he has the burden of re-engaging with his own language to come to terms with different codes of this language from colonial locations.

Ashcroft's insightful contentions find affinity with Homi Bhabha's The Location of Culture which analyses the slyness of imitating (Mimicry and the ambivalence of colonial discourse, 1994: 121). Imitating and at the same time shrewdly adopting a position that is oppositional is what characterises most postcolonial consciousness: "...colonial mimicry is the desire for a reformed, recognizable Other, as a subject of a difference that is almost the same, but not quite" (122). Ambivalence, indeterminacy and disavowal, Bhabha contends, are all markers of mimicry.

Ashcroft's articulations of abrogation and appropriation are also compatible with Bhabha's appropriation of menace as subtle strategic stance of the postcolonial subject:

The menace of mimicry is its double vision which in disclosing the ambivalence of colonial discourse also disrupts its authority. And it is a double vision that is a result of what l've described as the partial representation/recognition of the colonial subject. (126)

When one critically analyses this excerpt in terms of language in a broader perspective, it is undoubted that mimicry does not only menace but effectively weakens the strength of imperial language, conveying a myriad of issues in the postcolony. In other terms, menace is not just a threat of the postcolonial subject; it results in the re-orientation of language in diverse locations.

In the latter text, Post-colonial Transformation, Bill Ashcroft refers to hybridisation and ambivalence resulting from the positionality adopted by the colonial subject. He stresses linguistic empowerment with regard to the localised context of the language of colonial rule: "Language is a tool which has meaning according to the way it is used (57)... Mastering the master's language has been a key strategy of self-empowerment in postcolonial societies... (58)". The analogy discerned in the Alice and Humpty Dumpty dialogue is once more ascertained in terms of extending or creating different meanings with already existing language patterns.

Experience in language and meaning by speakers in the same culture and between those of different cultures operating with the same language conveys the sense in which one can construe whose superiority of the language counts. Postcolonial deployment of strategic ways of operating language in this perspective cannot be overemphasised. Ashcroft is apt in underscoring that "Words exist by means of languages, their horizons extending as far as the process of neologism, innovation, tropes and imagination will allow the horizons of the language itself to be extended" (70). This situates the operational use of English not as a language of conquest, but as a language of negotiating cultural spaces. Using language neologistically and creatively is a distinctive strategy of the postcolonial writer, Ashcroft asserts. This leads to a revaluation of the extent to which language is cultural capital from a broadened perspective beyond imperial coding. This results in the "other's" deflection of the narcissistic attitude of the imperial linguistic "self".

\section{The Postcolonial Writer/Scholar as Master of English Language/Literature: What Transformational Implications?}

Giving and taking in the global arena inevitably results in linguistic straddling and cosmopolitanism. To perpetuate African languages is undoubtedly vital to the survival of its linguistic authenticity, but to partake in the global cultural market 
means to give in to a language which does not prevent the visibility of African cultural positionalities in the global arena. This section re-evaluates creative choices made by writers to achieve and foster different aesthetic and cultural effects; it looks at the use of English in the hands of cultural icons who are neither celebrating Anglo-Saxon culture nor rerepresenting it through the language. One would recall that most giants of African literature like Senghor, Césaire, Kane, Ousmane, Tansi, Kourouma, Achebe, Soyinka, Head, Vera, Armah, Okigbo, p'Bitek, Emecheta, Mda etc. did not write in French or English to celebrate these languages and the cultures they represent. They primarily addressed African issues in connection with the outside world. They studied and mastered Western literature and civilization, and if they reproduced it at all, it was usually on transformational grounds of sly mimicry, mockery and parody.

In global literary and cultural trends, English is not a dominating language but a strategic communicative medium used by many. This has effectively weakened British grip to the language as mark of its cultural strength. African languages are surviving and still playing a vital role in cultural identity and representation. African languages are studied in Western universities today. All those who write in African languages are no doubt contributing enormously to cultural perpetuity linguistically - they are producing texts that will attract global appeal some day, if not already. The trend today is that most important postcolonial texts have been written in former imperial languages which assume nuanced codifications different from the previous dominance of imperial epistemology. The majority of these writers are capable of writing in an African language but are persistently continuing in English, representing African cultural realities rather than preoccupying themselves with African linguistic codifications. And in spite of this, they are not doing any disservice to African languages and cultures.

Dismantling the myth that English represents the unique cultural capital of Britain takes centre stage at this point. The United Kingdom is far from being a common linguistic entity, with the Irish, Scots and Welsh making claims to distinctive languages other than English. English itself has variations in England and cannot be romanticised as a unique and unanimous model of expression in the postcolony. The question of language as cultural capital evoked by Ashcroft becomes problematised the more. That culture is likened to an enterprise whose capital is language is very ambivalent today, particularly with colonial languages. The fervent conviction here is that culture is capital itself. Language is one of culture's assets; it is not all-embracing of culture, and this is the specific direction in which postcolonialism has used colonial language to its best interests.

Debates on who is native and non-native speaker of English are still inscribed in the erroneous binary of the English man's linguistic superiority over his colonised subject's inferiority. Hackert (2009) argues that being native speaker

[...] conjures up a sense of being born to a speech community and thus language, which implies a naturally determined, inalienable, and perfect competence and therefore right to ownership, and connects linguistic identity and political membership by way of the idea of nation. (306)

Such a position is compatible with the arguments of the venerated Ngugi wa Thiong'o regarding African identities. But in a world of constant human displacement and mobility, such a position connotes utopia and needs to be reconstructed. Language cannot be naturally determined, let alone perfected to suit a specific linguistic and political membership on grounds of a speech community. A Cameroonian who is born and raised in the UK will not automatically feel British because of excellent mastery of English. Likewise, an African who has studied English as first language in Africa cannot claim to be British in taste and manners. We are all born in a cultural location and in as much as the language associated with that location is vital, no one was ever born with a language. I think the use of labels like native and non-native speakers of English in today's debates should have little or nothing to do with mastery of English as a global and re-colonised language.

In postcolonial discourse the term 'non-speaker' is disturbingly ambiguous. Most, if not all postcolonial writers using English today, tend to be more 'native' than English counterparts because of the act of double mastery; double mastery in the sense of both knowing the master's language and devising ways of inflecting and subverting the language in a different cultural trajectory to suit African ways. The term native goes beyond British geographical space today; it covers any location of mastery. In like manner, expressions like 'English as second language' and 'foreign language' are becoming dizzying in the debate. If we consider the case of Cameroon on which we will briefly talk, there used to be pedagogic correctness in justifying the difference between Teaching English as Second Language (TESL) and Teaching English as Foreign Language (TEFL) under constitutional laws which prescribed English and French as equal official languages. This resulted in Anglophone Cameroonians learning English as second language and French as foreign language and vice versa for Francophones learning French as second language and English as foreign language. The point is that any Cameroonian Francophone creative writing in English is not considered Anglophone literature on 
fallacious grounds of inadequate mastery. Does it really matter if the writing context celebrates Cameroon and not English? The paradox is that there are many educated francophone Cameroonians who master English impeccably.

Ashcroft's thesis on transformation talks about the vast nature of cultural difference and experience as well as the complex ways in which such difference is communicated. He asserts that postcolonial writers install such difference with linguistic variance to establish a subtle form of distance. This linguistic variance is a kind of interpolation which Ashcroft names "metonymic gap":

The metonymic gap is that cultural gap formed when appropriations of a colonial language insert unglossed words, phrases or passages from a first language, or concepts, allusions or references which may be unknown to the reader. Such words become synecdochic of the writer's culture - the part that stands for the whole - rather than representations of the world, as a colonial language might. Thus the inserted language 'stands for' the colonized culture in a metonymic way, and its very resistance to interpretation constructs a 'gap' between the writer's culture and the colonial culture. (75)

Code-switching is clearly perceived not in the sense of semantic or register alterations of the same language, but other linguistic intersections which leave the Western reader fragilised and at times incapacitated to discern full textual meaning without trying to engage with the strategically infringing language. My experience in teaching postcolonial literature in a European university (University of Munich - Germany) leaves me with no doubt as to the concrete validity and importance of Ashcroft's articulations. Students easily identify instances of code-switching, the metonymic gap which disrupts their expectations in reading literary texts from Cameroon Anglophone literature. Worthy to note is that this distancing is a subtle invitation to engage mutually with the culture of the creative writer.

The imperial myth of the coloniser's language as his cultural capital, which has constituted a sole prerogative, does not exist anymore. One cannot say that Soyinka's Yoruba consciousness or Achebe's Ibo cultural texts are fostering English culture in their creative texts because they write in English. Whose images, aesthetics and meaning in their texts and from which cultural repertoire these count, should be a fundamental question in understanding their unassimilated display of the language. Distancing becomes a strategic way by postcolonial writers of engaging the so called native speakers in a complex double linguistic space. Distancing is a diplomatic cultural invitation.

Studies in English have not eclipsed and may never eclipse African languages, in fact, colonialism and imperialism did not annihilate a language. Linguistically, Africa can claim English as cultural capital, using it in such ways as to suit its various contexts. The expression "local colour" has quite often been used in most postcolonial writing. This expression is arguably an extended metaphor of transformation. One reads and learns much of Yoruba and Igbo cultures from Soyinka and Achebe respectively in English. They succeed as many other writers in translating, interpreting and representing cultural thought patterns, meanings and images with mastery of the English language. An obvious argument would be that translation means deconstruction; certainly true. But the language of translation is deconstructed as well, because it communicates a different cultural epistemology. Not using Ibo and Yoruba languages does not signal their insignificance as cultural asset. When one reads such classics as Things Fall Apart and Arrow of God, one realises that Achebe was true to his convictions of translating and transposing his culture on a global scale with English. These works are largely infused with Ibo lexicon, constituting metonymic gaps, and richly packed with proverbial grandeur drawn from Ibo oral repertoire. The general outlook of Ibo culture is finely textualised in the story. Transcultural aspects of the texts are not imperceptible.

In Things Fall Apart, two complex issues centre on Okonkwo's predicament; the killing of Ikemefuna and his act of suicide. If one argues critically that typical Ibo culture doubly eliminates Ikemefuna, it would be plausible also to contend that Achebe dismisses Okonkwo disgracefully on grounds of his cultural excesses in an inevitably mutable society. The divine will of the oracle to kill Ikemefuna cannot be transgressed. But Okonkwo must not be the one to execute or finalise the act of killing his adopted son. Okonkwo does this because he must safeguard his pride and manliness as an Ibo cultural exigency. The anxiety of his masculinity psychically abating is the driving force behind his determined resolve to action to safeguard this masculinity. Yet he stands alone when one would have expected him to be propelled to greatness as cultural icon, especially as he ruthlessly challenges the new infringing order. His son, Nwoye, defies his authority by joining the mission. Suicide is the only option to disentangle him from this new existentialist confusion. It is a dishonouring way to die in Ibo culture and he is not given appropriate burial as the laws of the land prescribe. His death and burial are not signals of the end of the culture he has uncompromisingly stood for with adamantine energy. The contention that Achebe puts off Okonkwo from the scene is tenable because his essentialist and totalising philosophy does not fit Achebe's transcultural reflections. Through this text, Achebe is trying to avoid the cultural essentialism of the West by conquering it through a compromising postcolonial third space.

Arrow of God testifies more to Achebe's excellent display of cultural intelligence. The chief priest Ezeulu happens 
to be the one who intellectually philosophises that to understand the outsider is to plant one's own signpost in the outsider's territory. Ezeulu sends his own child to study the white man's ways. This is not to fracture or destabilise the tradition he epitomises, but to adopt a strategic position on how to deal with the unavoidable new order. The fame of Achebe's Things Fall Apart was not so much the English language which inadvertently played an indisputable role in rendering it accessible, but the extent to which he could capture and textualise cultural identity and encounters, and prefigure a consciousness of cross-cultural spaces. Soyinka should not have deserved the 1986 Nobel Prize for literature based on the language of his literary/creative expression. The strength of his writings lay partly in his immense contribution to Yoruba, African and world cultural heritage.

\section{Trends in Cameroon Anglophone Literature}

We will at this juncture showcase Cameroon literature of English expression in the preceding arguments. Cameroon Anglophone literature is a synergistic literary space which has fostered the trend of seminal African literary minds. The corpus of this literature, likened to a vast and rich but insufficiently exploited mine, deserves transnational and international attention. Put in economic metaphor, it is literature which has attractive investment interests. This essay only surveys a very small part of the Cameroon Anglophone literature vast corpus; it is therefore an intellectual and academic invitation to more critical ventures into the literature. Culturally and linguistically speaking, Cameroon, widely known as Africa in miniature, is a multiethnic and multilingual country with more than 281 surviving languages, and 166 of which are standardised (Ngefac 2010: 152). This linguistic variety and survival lend credence to the fact that German, English and French colonialism neither eclipsed nor eroded the home languages of Cameroon. The complex issue is to reach a consensus on which of these languages should serve official and international purposes without untold anxiety within and without the country. While English and French remain the official languages of the country, its linguistic policies, through diverse agencies, enhance the promotion of its national languages. Cameroon Anglophone literature carries with it semantic contests, but has come to be considered as literature written by English-speaking, or more precisely Anglophone Cameroonians, who form a minority in the dominantly French-speaking country.

The writing of literature in English from this postcolonial African space validates Narayan's, Rushdie's, Achebe's and Ashcroft's articulations on the transformative nature of language, and transcultural strategies of the writers. About fifty years of different generations of Cameroon Anglophone writing have not been an issue of valorising the English language and promoting English culture. The literature has been addressing issues of the country's historiographies, temporalities, and political, economic, ethnic and socio-cultural realities amidst continental and global mutations. Vital aspects of Nso culture of the Nso people of the North West Region of the Cameroons is the heart of Kenjo Jumbam's and Tanla Kishani's transcultural creative engagement. The strength of Jumbam's The White Man of God is comparable only to Achebe's Things Fall Apart when cultural encounters and straddling are concerned. Jumbam uses English, not Lamnso, but he represents the Nso people and their struggles to accommodate a foreign culture without losing sight and touch of theirs. He invests in one of his protagonist, Yaya, a philosophical mindset which represents an alternative epistemology to the infringing Christian engineered one from the West. Just like Achebe, he engages in linguistic crisscrossing and translates oral culture into English. The text is replete with a vast array of dynamic cultural life such as ritual performances, song and dance, attire, cosmological views, ethics, etc. Jumbam touches on all the different structures of culture. The death of Big Father, who defies the tradition of the people because of his overzealous, essentialist and exclusionary Catholic Christian faith, has cultural and existentialist implications. He kicks and unmasks the representation of the strongest cult of the land, the Kibarankoh. He is utterly shocked to realise that the mask is worn by the chief catechist, Pa Matthew, whose sly mimicry is an irreparable blow to the priest's very existence. Big Father collapses never to recover. Just like Okonkwo, Big Father has no place in Jumbam's transcultural agenda. Jumbam is culturally dynamic enough to juxtapose Big Father with Father Cosmos, whose Christianity is not customised on imperialist grounds as that of Big Father. Father Cosmos interacts with the people, learns their language, eats their food, drinks their wine and home brewed liquor, adapts to their cultural difference and genuinely wins their hearts. The Nso people do not reject Christianity; they reject Big Father's curious unaccommodating Catholic theology.

For a writer who has been schooled and trained under austere Catholic circumstances, it is difficult to reconcile Kishani's orthodox background and the deeply rooted cultural substance of his poetry collection Konglanjo. Would one say that this text betrays his Western religious upbringing? Certainly not! He has not lost sight of his cultural rootedness in Nso. Incantations, ancestral invocations, ritualistic performance, song culture and communal aesthetics are the typical issues about Nso with which the poet is concerned. The collection's characteristic intermittent code-switching renders visible Nso language. This text points to English as a language dislodged from its imperial base; it is (in/de)flected, 
domesticated, fractured and utilised to serve different cultural needs. Bole Butake's And Palm Wine Will Flow is structured on a typical traditional regime of governance, probably drawn from his Noni cultural root, to appropriate contemporary questions of postcolonial leadership and the (ab)uses of power. The play wrestles more with the reader's engagement with two cultural and political systems in search of synergy rather than with the language of its expression, English.

Bakossi and Lebialem form great cultural substance in Alobwed'Epie's The Lady With A Beard and Linus Asong's A Crown of Torns, No Way to Die and Nkemngong Nkengasong's Across the Mongolo and Nol Alembong's Forest Echoes. Moghamo and Meta partly form the mettle of Margaret Afuh's Born Before Her Time, Shadrack Ambanasom's Son of the Native Soil and Albert Sama's Engwari. Not only the creating of metonymic gaps characterise their works, they also translate culture into English. These texts are not compartmentalised only in the matrices of cultures in Cameroon; they have wider implications in transnational and global exigencies.

Contrary to Ashcroft's observation on unglossed lexicon and syntax used by postcolonial writers as strategic distancing, most of Cameroon Anglophone writers have been generous enough to provide glosses to words and expressions when code-switching and creating metonymic spaces. Kishani's Konglanjo is an apt example. Its gloss both translates and interprets Lamnso words and expressions. In Forest Echoes, Alembong also provides a glossary in Nweh. Alobwed'Epie's The Lady With A Beard, an immense repertoire of Bakossi proverbs with enriching philosophical insight, is not glossed but provides parenthetical translations or explanations of Ekosse to the reader. These are very positive acts in transcultural negotiations. The present arguments try to prove that not using Yoruba, Ibo, Lamnso, Ekosse, Nweh, Moghamo as main medium of literary or theoretical expression does not mean impossibility of cultural identity and representation. It would be ideal to have literature from Cameroon's rich linguistic diversity associated with expressions such as "Lamnsophone literature", "Moghamophone literature", "Nwehphone literature", "Bayangphone literature", "Ekossephone literature", "Ewondophone literature", "Bassaphone literature", "Hausaphone literature", etc. This, however, would not resolve the problem of linguistic compartmentalisation and uncommon grounds of understanding on national, continental and global terms. If a colonial language can help in providing synergistic space for inter-cultural comprehensibility, particularly on the terms of the postcolonial writers' strength in cultural translation, it is a commendable move.

\section{Reassessing the Contention}

The best expression of a language and the power it wields is in its creative texture. An immense part of Western ideology was disseminated through its literature thanks to its long existing print culture. Britain and America are no longer the unique locations where one would appropriate literary uplifting of English expression. Today there is a big distance between using English and being Anglicised. The paradox of extended mastery is my fervent argument on what characterises the use of English in postcolonial writings. English is the same weapon with which the colonised needs to fight against the prejudices and hurt caused on the peoples of the colony. The saying goes that he who lives by the sword dies by the sword. When this is transposed to imperial language and postcolonial transformations, the language which was used against the colony is the postcolony's fundamental weapon used to weaken and disrupt that dominance and even dominate the language. The new literature born of this circumstance does not express English language's power but the power of the postcolonial discourses it articulates. As Rushdie has observed, the conquering of English is an act of liberation from its yoke. This discourse bears the imprints of the postcolonial subject's strength in fashioning imperial language to satisfy its taste which the English cannot do otherwise but acknowledge. This has been impressively done.

Harold Bloom's (1997) intertextual theory of the love/hate relation between precursor giants and emerging ephebes can be appropriated here with regard to influence, anxiety and anti-thesis - this is an influence which is non-assimilating, non-annihilating, non-eclipsing, but producing a new discourse which swerves, at times departs, without completely dissociating from the influence. The aesthetics of misreading and miswriting showcases the emergence of an undoubtedly significant transformation. The ephebe would never want to be a clone of the precursor; there exists an anxiety for distinctiveness which makes all the difference. Postcolonial authors consciously or unconsciously play this role. The colonised strongly masters the coloniser's literature and uses it menacingly, subversively, and at times aggressively, so that it results in the transformation of the coloniser as well. Sensitivity to language entrapment is a very preoccupying factor on the postcolonial writer. Intertextuality, mockery, subversion, and parody are strategically global concerns rather than the mere act of correcting erroneous typifications of the colonised.

The Commonwealth offers a synergistic space for cultural exchange between Britain and its former colonies. It is not a diplomatic imperial design of dominance by Britain, as some would think. Commonwealth games for example, are 
more of a space of great intercultural exchange and enrichment. While it uses English as common language of communication, the Commonwealth is not preoccupied with the promotion of any brand of the language. Britain today can pride itself with one of the world's leading centres of transcultural studies with a particularity of its imperial transformations - The University of London's School of Oriental and African Studies (SOAS) with a Centre for Cultural, Literary and Postcolonial Studies (CCLPS). Recognising its own transformation and negotiating new spaces in dialogue and global inclinations, Britain succumbs and validates the mark of the strategic acts of subversive mimicry. The Commonwealth is certainly neither a colonial nor neo-colonial weapon in the hitherto Macaulayan conception and agenda on Indian colonisation, but a representation of the transformation of Britain as a vulnerable former colonial and imperial master, however controversial and contested this might be.

\section{The Unarticulated but Visible Language}

The debate on language tends to give the impression that, without a people's original language, no other forms of cultural survival and articulation are possible. This is rather not true. Language itself has become a term with semantic shifts which go beyond the articulated and written, and also beyond paralinguistic variants. It also appears as if African languages must be promoted uniquely by its writers without which they cannot truly represent cultural identity through English language. But their acts of subverting imperial languages are plausible and laudable. Telling the world about the excesses of slavery, racism, colonialism and imperialism in a deflected and nativised Western language, in such ways of re-coding but effectively communicating and making heard, does not eclipse pre-colonial linguistic nationalism in postcolonial and post-independent Africans. As earlier said, Ngugi wa Thiong'o's coinage Afro-European literature is a seemingly explicit but highly sophisticated expression, because it carries with it semantic anxieties today other than Ngugi's intended meaning. There are more markers of re-colonising and re-orienting the mind, rather than decolonising the mind, in the writers who have been categorised as Afro-European. It should be re-iterated that Soyinka, Achebe, Okigbo, Armah, Bate Besong, Jumbam, Butake, Asong, Kishani etc. are not less concerned with culture and PanAfricanism than those who write in African languages, or linguists who are more concerned with language dynamics and development than its use in creative representation of culture and narration of the state/nation. Even with English they still engage with very palpable aspects of culture.

Ngugi wa Thiong'o's advocacy for the promotion of African languages remains indisputably justifiable even if postcolonial writing has gone beyond cultural nationalism from a linguistic perspective. African linguistics is a booming cultural industry today not only in Africa but in the West. With all these, language is incapable of doing everything for a culture. Dressing, food and eating habits, manners and behaviours, embroidery, sculpture, etc. pertain not only to paralinguistic issues about language but visible and non-articulated authentic culture. One must not use an African language to appreciate the cultural excellence of an African handicraft centre. Swahili is not a prerequisite of identifying a Masai in Kenya or beyond. Take for example Cameroon's appearance at the last two Olympic Games, the distinctiveness of its representation is not English, French, Lamnso, Moghamo, Ewondo, Fufulde etc., it is the dressing which now speaks and showcases for the variety of its culture. The outfit speaks for the country. Cameroon authorities did not adopt this approach to cultural showcasing by accident. The choice has been intentional and strategic. In such contexts written or spoken language becomes secondary. Beyond spoken and written language, culture is still visible or discernable.

\section{Conclusion}

This paper has tried to bring more reflection to, and shed more light on an existing complex and unending debate. To enliven and re-engage the debate for intellectual re-thinking and revitalisation, the essay has argued on the vulnerability of imperial language (specifically English) as a transformational tool in postcolonial transcultural discourse. This susceptibility does not mean the dismantling or annihilation of English. It signifies eroding English as the master code of imperialist dominance and using it in such ways as to suit postcolonial needs through creative writing. English is a powergenerating metaphor; it is mutually constitutive, engendering both the coloniser and colonised as repositories or sites of power. In this matrix, English is used in the postcolony for cultural transmission and for the alteration of colonial and imperial dominance. Postcolonial writers are not bondsmen, but committed agents in the polyvocality of cultures and other diverse discourses in postcolonial spaces and the ever changing global context. 


\section{Acknowledgments}

The research leading to this academic paper has received funding from the European Union Seventh Framework Programme [FP7 (2007 - 2013)] under Grant Agreement no PIIF - GA - 2011 - 298634 CAMLIT.

I would also like to express gratitude to the Bayreuth International Graduate School of African Studies (BIGSAS) University of Bayreuth for permitting me to explore its rich library and providing me research space. I am particularly indebted to my academic soulmate in postcolonial studies Gilbert Ndi Shang. Our research engagements and dialogues have been constantly enriching pre-texts to texts like this essay. His personal library of postcolonial and multicultural studies has been of invaluable help.

\section{References}

Achebe, Chinua. "English and the African writer," Transition: a journal of the arts, culture and society, 4.18 (1965): 27 - 30.

Adejunmobi, Moradewun. "Routes: Language and Identity of African Literature," Journal of Modern African Studies 37.4 (1999): 581 596.

Afolayan, Shina. "The Question of Post-colonial Culture: Language Ideology and Cultural Essentialism," 2002. <English.chass.ncsu.edu /jouvert/v7is1/afola.htm>

Ambanasom, Shadrack. "Cameroon Creative Writers and the Language Problem." [2001] Perspectives on Cameroon Literature in English. Kansas City: Miraclaire Academic Publications, 2012. 45 - 57.

Asante-Darko, Kwaku. "Language and Culture in African Postcolonial Literature," CLCWeb: Comparative Literature and Culture 2.1 (2000): <http://dx.org/10.7771/1481-4374.1062>

Ashcroft, Bill. Post- Colonial Transformation. London: Routledge, 2001.

Ashcroft, Bill, Gareth Griffiths, and Helen Tiffin. The Empire Writes Back: Theory and Practice in Post-Colonial Literatures. New York: Routledge, 1989.

Bhabha, Homi K. The Location of Culture. London: Routledge Classics, 2004.

Bloom, Harold. The Anxiety of Influence: A Theory of Poetry. New York: Oxford University Press, 1997.

Carroll, Lewis. Alice's Adventures in Wonderland and Through the Looking Glass and What Alice Found There. Ed. Haugh Haughton. London: Penguin, 1998.

Chinweizu et al. Toward the Decolonization of African Literature. Washington: Howard University Press, 1983.

Guthrie, Abigail K. Language and Identity in Postcolonial African Literature: A Case Study of Chinua Achebe's Things Fall Apart. Unpublished Diss. School of Communication, Liberty University. 2011.

Hackert, Stephanie. "Linguistic Nationalism and the Emergence of the English Native Speaker." Ejes - European Journal of English Studies 13/3 (2009): $303-17$.

Kunene, Mazisi. "Problems in Africa Literature," Research in African Literatures, 23. 1(1992): 27 - 44.

Mugambi, Helen Nabasuta. "Speaking in Song: Power, Subversion and the Postcolonial Text," Canadian Review of Comparative Literature. 2005. 420 - 431.

Narayan, R K. A Writer's Nightmare: Selected Essays 1958-1988. London: Penguin Books, 1988.

Ngefac, Aloysius. "Linguistic Choices in Postcolonial Multilingual Cameroon" Nordic Journal of African Studies. 19. 3 (2010): 149 - 164.

Ngugi, wa Thiong'o. Globalectics: Theory and the Politics of Knowing. New York: Columbia University Press, 2012.

Ngugi, wa Thiong'o. Moving the Centre: The Struggle for Cultural Freedoms. London: James Currey, 1993.

Ngugi, wa Thiong'o. Decolonising the Mind: The Politics of Language in African Literature. Portsmouth, NH: Heinemann, 1981.

Ojaide, Tanure. "African Literary Aesthetics: Continuity and Change," Journal of the African Literature Association. 6. 2 (2012): 114 132.

Ojaide, Tanure. Poetic Imagination in Black Africa: Essays on African Poetry. Carolina: Carolina Academic Press, 1996.

Olatunji, Sunday Agboola. "Thematic changes in postcolonial Africa literature: From colonialism to neo-colonialism," Sino - Us English Teaching. 7. 10 (2010): $125-134$.

Owomoyela, Oyekan. "Language, Identity, and Social Construction in African Literature," Research in African Literatures, 23. 1(1992): 83 -94 .

Pacheco Pinto, Marta. "Postcolonial Language: Rejection and Subversion," Babilónia. Revista Lusófona de Línguas, Culturas e Tradução. 8 - 9 (2010): 65 - 83.

Rushdie, Salman. Imaginary Homelands. New York: Granta, 1992.

Thomas, Dominic. Nation - Building, Propaganda, and Literature in Francophone Africa. Bloomington: Indiana University Press, 2002.

Walcott, Derek. "The Muse of History," The Post-Colonial Studies Reader. (eds) Bill Ashcroft, Gareth Griffiths, and Helen Tiffin. London: Routledge, 2006. 329 -332. 
